\title{
An Analysis of Long-Term Forest Management Plans of Forest Management Units in Sumatra, Indonesia
}

\author{
Masahiko Ota ${ }^{1}$ \\ ${ }^{1}$ Kyushu Institute of Technology, Japan \\ Correspondence: Masahiko Ota, Kyushu Institute of Technology, Japan. E-mail: ota@ltc.kyutech.ac.jp \\ Received: February 5, 2018 \\ Accepted: March 20, $2018 \quad$ Online Published: May 30, 2018 \\ doi:10.5539/jsd.v11n3p96 \\ URL: https://doi.org/10.5539/jsd.v11n3p96
}

\begin{abstract}
Indonesia has been developing Forest Management Units (FMUs) as on-site forest managers that undertake actual forest management activities at the field level. Previous studies have identified a critical lack of various resources, particularly human and financial, in FMU development, and yet the types of forest management activities and official planning procedures are less frequently reported. The present study examines forestry planning aspects of the FMU policy and forest management activities planned by FMUs to fill this information gap. The author analyzed relevant laws and regulations and the long-term forest management plans of 22 FMUs in Sumatra. For the latter, the author explored basic characteristics of FMUs, quantitatively summarized planned activities focusing on four aspects of forest management (i.e., utilization, conservation, empowerment of local people, and supervision of concession holders), and qualitatively assessed the levels of concreteness of plan descriptions related to the above-mentioned four aspects. The FMUs listed various kinds of activities in their long-term plans, particularly those related to utilization and conservation. However, a large number of the sample FMUs simply listed or described what they would like to do, or what FMUs are supposed to do, with little concrete detail or deliberation of feasibility. The results of the study can be attributable to a lack of focus on policy formulation, as well as the vulnerability and unpredictability of FMUs themselves. Qualitative enhancement and quantitative increase of human resources and policy options to reduce unpredictability and uncertainty in financial and institutional dimensions are desirable to promote substantive planning for FMUs.
\end{abstract}

Keywords: forestry planning, forest management activities, tropical forest, governance

\section{Introduction}

Forest sector reform is ongoing in many tropical countries. Given the context that tropical forests were mostly nationalized during the colonial period, and that local people's access to forests had been limited, reform typically has typically involved decentralization, devolution, community-based, or participatory approaches (Springate-Baginski \& Blaikie, 2007). Tenure issues are often associated with the participatory processes (Sunderlin et al., 2008; Bluffstone \& Robinson, 2014). Capacity development of forest administration is another aspect of forest sector reform; donor agencies may carry out capacity-building projects for forest officers (Gesellschaft für Internationale Zusammenarbeit [GIZ], 2011; The Center for People and Forests [RECOFTC], 2016). Lastly, apart from utilizing existing organizations, governments may develop new kinds of organizations in order to make forest management effective or substantive.

Indonesia has been at the forefront of tropical deforestation and forest degradation issues (Margono et al., 2014). There is a common understanding that tropical rain forests in Indonesia's outer islands (e.g., Sumatra, Kalimantan, Sulawesi, Papua, and others) have not been managed properly, particularly due to unclear property rights arrangements and the absence of substantive forest management institutions (Ministry of Forestry [MoF], 2011). Provincial or district forestry services had been operating prior to the implementation of the Forest Management Unit policy, and yet they were not organizations that had the capacity to undertake actual forestry management or planning (Ngakan et al., 2005). Unsustainable behaviors, such as the companies holding logging or industrial timber plantation concessions, were common (Hurst, 1991; Limberg et al., 2007).

Indonesia's Forest Management Unit (FMU, or KPH in Indonesian) policy is a form of forest sector reform. FMUs are a new kind of organization for the management of such state forests in Indonesia's outer islands (Ota, 2015). The FMU policy has been one of the most prominent initiatives introduced in Indonesia's forest sector (Ministry of Environment and Forestry [MoEF], 2015). As of December 2017, a total of 430 FMUs have been 
organized (MoEF, 2017). The FMUs are categorized into the areas of Production, Protection, and Conservation in accordance with the functionary categories of Indonesia's state forests. Of the 430, 288 are Production and 142 are Protection FMUs. No Conservation FMUs, which are to be organized for protected areas, have yet been established.

FMUs are expected to be on-site forest managers that undertake actual forest management activities at the field level, whereas existing provincial or district forestry services are in charge of administration; they co-exist (Ota, 2015). FMUs develop a basic institutional infrastructure for forest management; e.g., demarcated boundaries, inventory, maps, blocks or compartments. They also coordinate or supervise stakeholders involved in their management areas, including local people and concession-holding companies. They formulate long-term and short-term forest management plans for the activities of the next 10 years and one year, respectively.

However, a critical lack of various resources, particularly human and financial, has been identified both by evaluation reports (MoF, 2011; MoEF, 2014; Setyarso, 2016) and scholarly articles (Bae et al., 2014; Ota, 2015; Kim et al., 2016; Fisher et al., 2017). In addition, unclear and inadequate institutional provisions and authority related to what FMUs can do, including monitoring and supervision of concession-holding companies, is also reported as an implementation constraint (Ota, 2015). In addition to the analysis of implementation, analysis has also been conducted of the power struggles between central and local governments over control of state forests through the FMU policy (i.e., "recentralization") by the central government (Sahide et al., 2016a; 2016b). Previous studies related to FMUs reveal some of the dilemmas of new organizations in the tropical forest sector; i.e., the organizations have to do something, but every resource is scarce and institutional provisions are unclear with conflicting stakeholder interests. Various constraints on implementation, such as material, human, informational and financial resources and technological and normative constraints (Mendes, 2006), are evident.

The present study aims to provide information on the forestry planning aspects of FMU policy and actual forest management activities planned by FMUs. In the previous literature, despite the indication of various challenges related to FMU development, the types of forest management activities that FMUs are actually trying to conduct are less frequently reported. In addition, official planning procedures in FMU policy are also less well known. Clarification of what FMUs are actually trying to do in their management areas would be valuable information to consider as future FMU policies are developed.

\section{Methods}

\subsection{Materials}

The present study has a two-tiered analytical structure, an institutional analysis of the FMU planning system and an analysis of the activities planned by FMUs.

Regarding the first point, FMU-related regulations and information books are available online at MoEF (2017). The author extracted information from this website. In addition, there are "informal" aspects of planning that may not be clearly articulated in the official documents. The author visited the Ministry of Environment and Forestry in Jakarta in August 2015 and August 2016, and in Lampung province in February 2013 and West Sumatra province in November 2016, both in Sumatra. The author obtained supplementary information about such "informal" aspects through interviews with forestry officials.

For the second point, the author examines ten-year, long-term forest management plans, which every FMU is required to formulate, in order to understand the activities intended for FMU management areas. This is because an analysis of formalized plans can convincingly elucidate how FMUs expect to manage forests over the coming years.

The author draws on the long-term forest management plans prepared by 22 FMUs located in Sumatra. The geographical distribution of the 22 FMUs is presented in Figure 1: eight in Lampung, four in West Sumatra and South Sumatra, two in Riau, and one each in North Sumatra, Jambi, Bengkulu, and Bangka-Belitung provinces. The author obtained the data from the then Directorate-in-charge of FMUs in the Ministry of Environment and Forestry in August 2015; these were all the long-term forest management plans authorized and available at that time. 


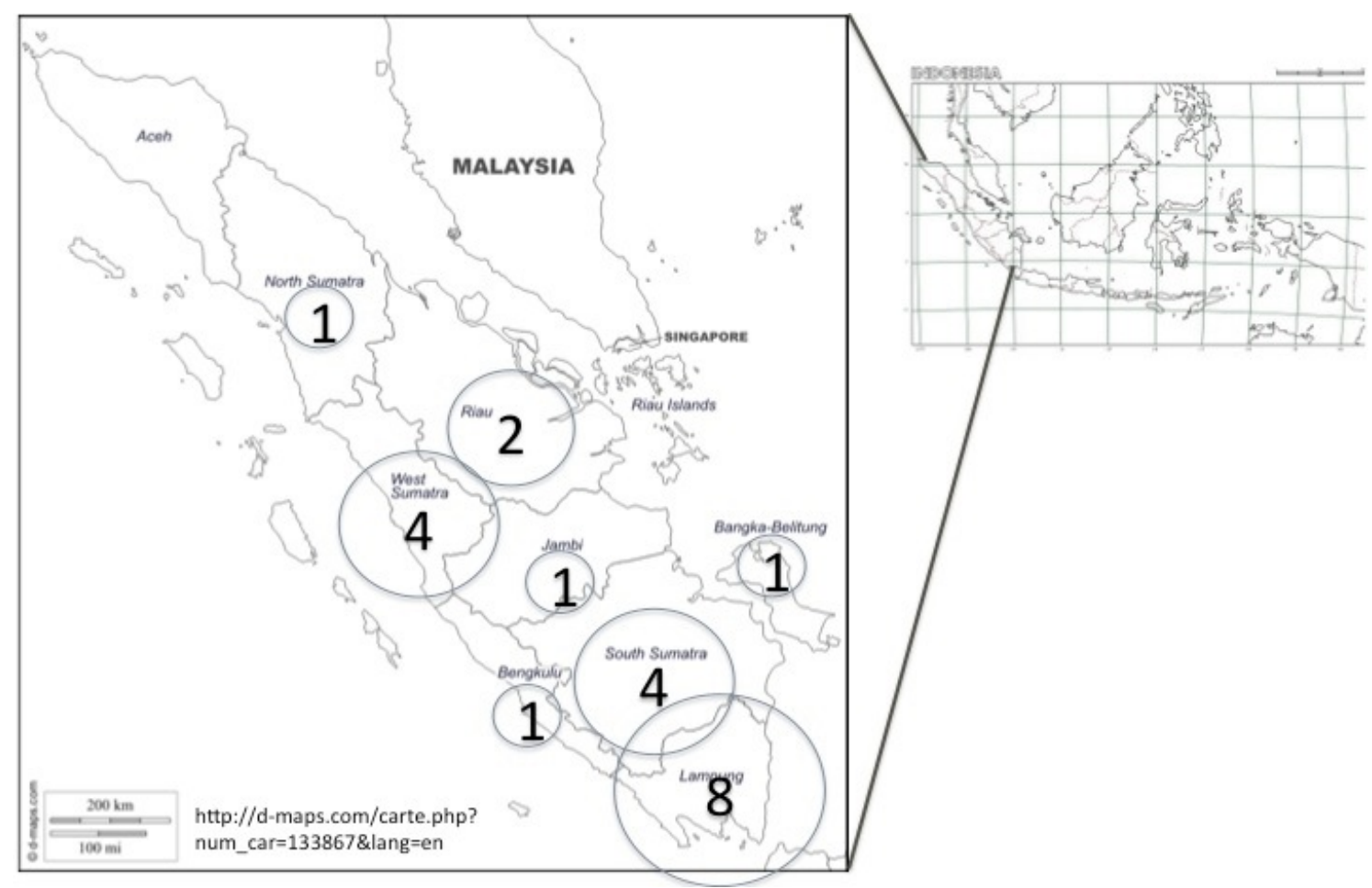

Figure 1. Geographical distribution of the analyzed 22 FMUs in Sumatra, Indonesia; numbers indicate the numbers of analyzed FMUs located in each province

The present study strategically focuses on Sumatra. Indonesia is a diverse country, and situations of forest management also vary across islands and regions. "Outer islands" of Indonesia, Sumatra, Kalimantan, Sulawesi, and Papua, are mostly tropical rain forest regions and have been subject to unsustainable exploitation and development pressure (Hurst, 1991; Damayanti \& Prasetyo, 2015; Ota, 2015). Among others, Sumatra has been at the forefront of ecological and social problems related to large-scale concession for timber logging, industrial plantations, and oil palm plantations and related to unauthorized forestland cultivation by local people. One of the FMU objectives is to properly and sustainably manage such forests with the extensive presence of concessions and conventional local use, and therefore the author focuses on Sumatra.

\subsection{Analytical Framework}

For the first point, the author reviews the relevant laws and regulations and summarizes the planning institution related to FMUs. Information from the interviews with officials is also utilized.

Regarding the second point, the author firstly summarizes the basic characteristics of the 22 FMUs. As shown in the results, long-term forest management plans are to contain the chapters listed in Table 1. Here, the information in the chapter "(II) Description of the area" is consulted. This is to confirm the geographic and socio-institutional situations in which these FMUs operate, particularly in reference to concessions and conventional agricultural use (encroachment) by local people inside the FMU management areas. 
Table 1. The chapters in a long-term forest management plan and the sub-chapters of the chapter (V) Activity plan, specified in the technical guidelines from the Ministry of Forestry (P.5/VII-WP3H/2012)

\begin{tabular}{|c|c|c|c|}
\hline \multicolumn{2}{|r|}{ Chapters } & \multicolumn{2}{|r|}{ Sub-chapters in the chapter (V) Activity plan } \\
\hline I. & Introduction & a. & $\begin{array}{l}\text { Periodic inventory of management areas and } \\
\text { arrangements for forests (penataan hutan), }\end{array}$ \\
\hline II. & Description of the area & b. & Forest use in concession-free areas (wilayah tertentu) \\
\hline III. & Vision and mission & c. & Empowerment of people \\
\hline IV. & Analysis and projection & d. & $\begin{array}{l}\text { Development and control of concession-covered or } \\
\text { utilization-permit-covered areas }\end{array}$ \\
\hline V. & Activity plan & e. & $\begin{array}{l}\text { Rehabilitation of management areas outside } \\
\text { concessions }\end{array}$ \\
\hline VI. & $\begin{array}{l}\text { Development, supervision, } \\
\text { and control }\end{array}$ & f. & $\begin{array}{l}\text { Development and control of the implementation of } \\
\text { rehabilitation and reclamation in concession-covered or } \\
\text { utilization-permit-covered areas }\end{array}$ \\
\hline VII. & $\begin{array}{l}\text { Monitoring, evaluation, } \\
\text { and reporting }\end{array}$ & g. & $\begin{array}{l}\text { Implementation of forest protection and nature } \\
\text { conservation }\end{array}$ \\
\hline \multirow[t]{8}{*}{ VIII. } & Conclusion & h. & $\begin{array}{l}\text { Implementation of coordination of synchronization } \\
\text { among concession holders }\end{array}$ \\
\hline & & i. & $\begin{array}{l}\text { Coordination and synchronization with agencies and } \\
\text { stakeholders }\end{array}$ \\
\hline & & $\mathrm{j}$. & $\begin{array}{l}\text { Preparation and improvement of the capacity of human } \\
\text { resources }\end{array}$ \\
\hline & & $\mathrm{k}$. & Preparation of finances \\
\hline & & 1. & Development of databases \\
\hline & & $\mathrm{m}$. & Rationalization of management area \\
\hline & & n. & $\begin{array}{l}\text { Review of management plans (at least once in five } \\
\text { years) }\end{array}$ \\
\hline & & o. & Development of investment \\
\hline
\end{tabular}

(Actual contents of long-term forest management plans do not necessarily match this table precisely)

Second, activities planned for the next 10 years are quantitatively summarized. Activities planned for the next 10 years are to be documented in the chapter "(V) Activity plan" (Table 1). The author strategically focuses on four aspects of forest management, i.e., utilization, conservation, empowerment of local people, and supervision of concession holders. The former two represent part of the basics of forestry operations in general terms. The latter two are related to coordination with stakeholders; outside of the government sector, concession holders and local people are the two most important stakeholders in Indonesia's forest governance (Ota, 2015). The author reviews the sub-chapters corresponding to each issue in the chapter "(V) Activity plan" (Table 2), determines the major kinds of activities presented there, and identifies the number of FMUs that fit into each kind of activity.

Table 2. Analytical focus and the corresponding sub-chapters in the chapter "(V) Activity plan" shown in Table 1

\begin{tabular}{|c|c|c|}
\hline Broad category & Analytical focus & $\begin{array}{l}\text { Corresponding sub-chapters in the chapter "(V) Activity } \\
\text { plan", }\end{array}$ \\
\hline \multirow[b]{2}{*}{$\begin{array}{l}\text { Basic forestry } \\
\text { operations }\end{array}$} & Utilization & b. Forest use in concession-free areas \\
\hline & Conservation & $\begin{array}{l}\text { g. Implementation of forest protection and nature } \\
\text { conservation }\end{array}$ \\
\hline \multirow{2}{*}{$\begin{array}{l}\text { Coordination } \\
\text { with } \\
\text { stakeholders }\end{array}$} & $\begin{array}{l}\text { Empowerment of local } \\
\text { people }\end{array}$ & c. Empowerment of people \\
\hline & $\begin{array}{l}\text { Supervision of } \\
\text { concession holders }\end{array}$ & $\begin{array}{l}\text { d. Development and control of concession-covered or } \\
\text { utilization-permit-covered areas }\end{array}$ \\
\hline
\end{tabular}

However, quantitative counting alone may not provide insights into the concreteness of each activity plan; that is, 
formulators may simply list what they would like to do or what FMUs are supposed to do, without taking actual local situations or feasibility into consideration. Hence, and third, expressions related to planned activities in the sub-chapters in Table 2 are qualitatively assessed. The author applies the concept of rubrics. A rubric is "a scoring tool that lays out the specific expectations for an assignment" (Stevens \& Levi, 2013), and it is often used for assessing academic performances. Rubrics generally set three- to five-scale levels of performance, and explicitly describe the requirements for achieving each level. In the present study, performance includes the levels of concreteness of descriptions. The author developed a concise and general-purpose three-point scale assessment matrix to assess the levels of concreteness of plan descriptions (Table 3). Using this matrix, the author assesses each of the four sub-chapters listed in Table 2.

Table 3. Assessment matrix for levels of concreteness of plan descriptions developed by the author

\begin{tabular}{cl}
\hline Level & \multicolumn{1}{c}{ Conditions } \\
\hline Level 1 & $\begin{array}{l}\text { Simply listing or describing what they would like to do, or what FMUs are supposed to } \\
\text { do, with few concrete plans or methods }\end{array}$ \\
Level 2 & $\begin{array}{l}\text { Explaining the activities and their significance, but expressions are general and lack } \\
\text { local information or concreteness }\end{array}$ \\
Level 3 & $\begin{array}{l}\text { Describing concrete plans and methods for each activity, taking their local situations } \\
\text { into consideration }\end{array}$ \\
\hline
\end{tabular}

The author recognizes that forest management activities may be implemented even though plan descriptions are not very concrete, and vice versa, being affected by human, budgetary, and other resource availability. Qualitative assessments using rubrics offer a kind of supplementary information; the author's intension is to prevent the analyses from being superficial by combining qualitative and quantitative methods.

\section{Results}

\subsection{The FMU Planning System}

FMU staff formulates ten-year long-term and annual short-term forest management plans, reflecting actualities of each management area (P.6/Menhut-II/2009). The then Directorate General of Planning at the Ministry of Forestry provided technical guidelines for formulating these plans in 2012 (No P.5/VII-WP3H/2012). These guidelines establish a working team, consisting of the staff of FMUs, regional forestry services, technical implementation units of the Ministry of Forestry, and experts as necessary. It is stipulated to include ecological, economic, and social information.

However, although it is stated that socio-economic information should be included in long-term plans through local data collection processes, instructions for involving local people in planning or decision-making processes are not explicitly provided. From the author's interviews in Lampung in 2013 and West Sumatra in 2016, it was inferred that long-term plans had not necessarily been formulated with substantive consultation with local people.

Long-term forest management plans are supposed to contain the chapters shown in Table 1. In addition to these, appendices such as maps are also to be attached. Activities planned for the next 10 years are to be documented in the chapter "(V) Activity plan," as shown in Table 1, along with related appendices. It is understood that the ministry specifies the basic contents, and the uniqueness of each FMU will be reflected at the concrete activity-level.

From 2013 to 2015, it was stipulated that long-term plans would be formulated by the heads of FMUs. Plans that were already developed for the regional forestry service were submitted to the ministry, as well as to one of its regional units (PUSDAL), for endorsement (P.46/Menhut-II/2013). Beginning in 2015, it was stipulated that long-term plans would be formulated by provincial governments, with the heads of FMUs being assigned to this work. Plans were then to be endorsed by the Directorate-Generals in charge of production and protection of FMUs (P.64 Menlhk-setjen 2015). This would be in line with Sahide et al.'s (2016a) indication that developments of FMU institutions have been recentralized.

With regard to budgetary aspects of operations, FMUs can utilize national, regional, and external donors' budgets for their operations (P.20/ Menlhk-Setjen/2015). In long-term forest management plans, budgets for 
FMU activities are presented as projected estimates.

From the author's interviews in Jakarta and in West Sumatra in 2016, it was confirmed that FMUs request estimated annual budgets from the ministry with short-term forest management plans. Directorates in charge at the ministry review them and determine budgetary allocations for FMUs. From the same interviews, it was also confirmed that most of the budgets for FMUs were coming from the Ministry of Environment and Forestry, inferring FMUs' high dependence on national budget schemes.

As of January 2018, in total, 129 long-term forest management plans have been authorized in Indonesia, of which 88 are for Production FMUs and 41 are for Protection FMUs (MoEF, 2017). The percentages of Production and Protection FMUs with authorized long-term plans are $30.5 \%$ and $28.9 \%$, respectively.

\subsection{Basic Characteristics of the 22 FMUs}

Out of the 22 FMUs, 14 were Production FMUs, in which most forests are used for production purposes, and eight were Protection FMUs, in which most forests are to remain protected. Consequently, Protection FMUs tend to include greater mountainous or hilly areas. These 22 FMUs were all "Model FMUs", which were established earlier, by 2014, as advanced models of the FMU policy.

In terms of administrative levels represented, five were Provincial FMUs, which cross more than two districts and hence are established at the provincial level, and 17 were District FMUs, which are located inside one district and hence established at the district level (Note 1).

The management areas of FMUs were quite large. The average, minimum, and maximum management areas of 22 FMUs were 121,817ha, 5,160ha, and 513,276ha, respectively. Little systematic information on personnel resources was available from the plans. In one example, with an area of around 80,000ha, the current number of personnel was 15 people (one head, three sub-heads, and 11 officials). This FMU was planning to increase the number of personnel to 55 over the following 10 years. These facts suggest that it would be very difficult to manage such a large area with such a limited number of personnel.

Seventeen out of 22 FMUs had concessions inside their management areas. These were the concessions that had been implemented before FMUs were established. Surprisingly, five FMUs had more than $90 \%$ concession coverage in their management areas. Eleven FMUs, half of 22, had more than 30\% concession coverage (Figure 2). These facts suggest that FMUs were established in areas that had been covered with company concessions, and the ratios of concession coverage are high.

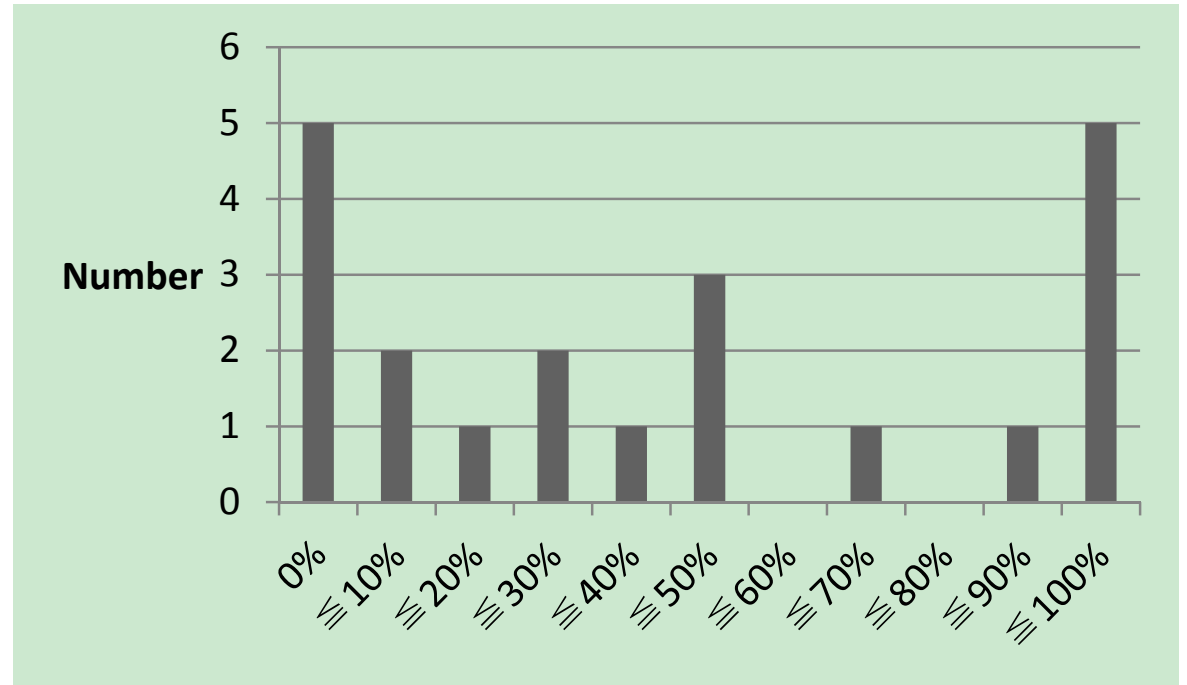

Figure 2. Number of FMUs by percentage of concession area to total FMU area ( $\mathrm{n}=21$ : one missing value)

All 22 FMUs were subject to agricultural encroachment, either shifting cultivation in dry fields or wet paddy cultivation. Eight out of 16 FMUs for which data of land use were available had more than $30 \%$ coverage of agricultural encroachment (Figure 3). This suggests that FMUs were established in situations where unauthorized local occupancy of forests was widely practiced, and the ratios of encroachment are high. 


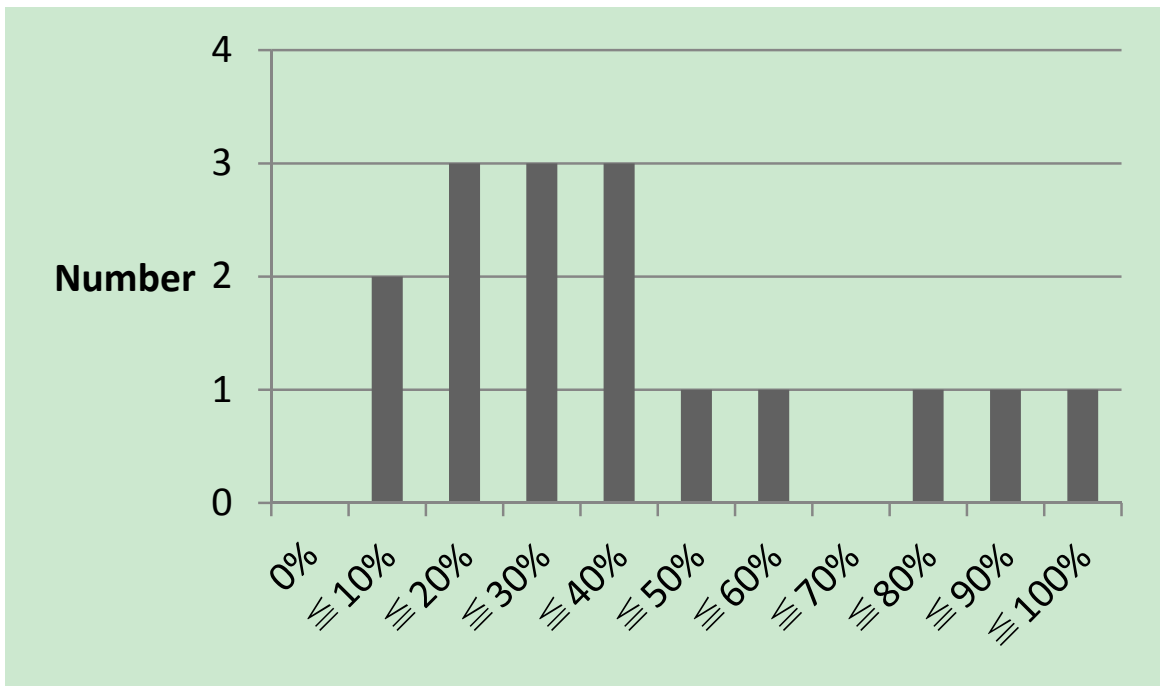

Figure 3. Number of FMUs by percentage of agricultural encroachment to total FMU area ( $n=16$ : six missing values)

The large FMU management areas suggest that the numbers of personnel are critically low. In addition, large portions of FMU areas had been covered with concessions and encroached upon before FMUs began to operate. These facts demonstrate that FMUs, in the first place, are difficult to operate within the existing legal and contextual uncertainty, with critically limited human resources.

\subsection{Quantitative Exploration of Activities Planned}

Regarding utilization, various activities were confirmed in the sub-chapter "(2) Forest use on concession-free areas" (Table 4). Among others, development of non-timber forest products (NTFPs) (71.4\%) and timber plans $(52.4 \%)$, ecotourism $(38.1 \%)$, and fish cultivation/animal breeding $(38.1 \%)$ were most popular. Seven FMUs (33.3\%) referred to REDD+/carbon activities. Six FMUs (28.6\%) referred to businesses (other than REDD+). The difference between "utilization" and "development" of timber or NTFPs is that existing resources are utilized in the former, and resources are newly grown or developed in the latter. NTFPs that the FMUs targeted included jelutung (Dyera costulata), aren (Arenga pinnata), agarwood (Aquilaria spp.), kayu putih (Melaleuca leucadendra), para rubber (Hevea brasiliensis), pine resin, rattan, etc. As mentioned later, not much concrete information was available for a large portion of these activities in terms of what FMUs are actually accomplishing.

Table 4. Kinds of activities planned for utilizing concession-free areas and numbers of FMUs that list them $(\mathrm{n}=21$ : one FMU had no concession-free area)

\begin{tabular}{llrr}
\hline & & $\begin{array}{c}\text { Number } \\
(\mathrm{n}=21)\end{array}$ & \% to total \\
\hline \multirow{3}{*}{ Timber or } & Utilization of timber & 5 & 23.8 \\
NTFPs & Utilization of NTFPs & 7 & 33.3 \\
& Development of timber plants & 11 & 52.4 \\
& Development of NTFPs & 15 & 71.4 \\
\hline \multirow{2}{*}{ Ecosystem } & Utilization of water & 2 & 9.5 \\
services & Ecotourism & 8 & 38.1 \\
& REDD+/utilization of carbon & 7 & 33.3 \\
\hline \multirow{3}{*}{ Others } & Development of seedlings & 2 & 9.5 \\
& Fish cultivation/animal husbandry or breeding & 8 & 38.1 \\
& Hydropower generation & 1 & 4.8 \\
\hline \multirow{2}{*}{ With third } & Business/investment & 6 & 28.6 \\
parties & Co-management with local people & 5 & 23.8 \\
& Research and Education & 3 & 14.3 \\
\hline
\end{tabular}


Various kinds of conservation-related activities were also confirmed (Table 5). Almost all (95.5\%) of the FMUs referred to routine patrol or protection, and eight FMUs (36.4\%) mentioned plans for special policing operations that would include forest police or the Indonesian army. Fifteen FMUs (68.2\%) referred to prevention, control, and identification of forest fires, and six FMUs (27.3\%) mentioned that they would organize occasions for practice in extinguishing fires. Relationships with local people were also regarded as important components, with edification, extension and facilitation for local people (31.8\%) and collaboration with local people (13.6\%). Other than these, enhancing infrastructure for forest management was also confirmed, in which $36.4 \%, 36.4 \%$, and $31.8 \%$ of the FMUs referred to delineation and identification of areas for protection, setting notice boards/ enhancing the functioning of boundaries and FMUs, and inventory of encroachment.

Table 5. Kinds of activities planned for conserving forests and numbers of FMUs that list them $(\mathrm{n}=22)$

\begin{tabular}{llrr}
\hline & & $\begin{array}{r}\text { Number } \\
(\mathrm{n}=22)\end{array}$ & $\begin{array}{r}\% \text { to } \\
\text { total }\end{array}$ \\
\hline Patrolling or & Routine patrol or protection & 21 & 95.5 \\
policing & Special policing operations & 8 & 36.4 \\
\hline \multirow{2}{*}{ Fire management } & Prevention, control, and identification of fires & 15 & 68.2 \\
& Practice extinguishing fires & 6 & 27.3 \\
\hline Relationship with & Edification, extension, and facilitation for local people & 7 & 31.8 \\
local people & Collaboration with local people & 3 & 13.6 \\
\hline Enhancing & Delineation and identification of areas for protection & 8 & 36.4 \\
infrastructure for & Setting notice boards/ enhancing the functioning of & 8 & 36.4 \\
forest & boundaries & 7 & 31.8 \\
\hline management & Inventory of encroachment & 10 & 45.5 \\
\hline \multirow{2}{*}{ Others } & Protection of high conservation value forests & 3 & 13.6 \\
\hline
\end{tabular}

With regard to empowerment of local people, 15 FMUs (68.2\%) referred to developing concessions for local people such as People's Plantation Forests (HTR), Community Forests (HKm), or Village Forests (HD), or some partnership-based reforestation activity not in the form of a concession (Table 6). Eleven FMUs (50.0\%) mentioned a plan to develop or enhance farmers' groups as part of livelihood improvement. Nine FMUs (40.9\%) mentioned that they would offer some training opportunities for local people related to timber or NTFPs.

Table 6. Kinds of activities planned for empowering local people and numbers of FMUs that list them $(\mathrm{n}=22)$

\begin{tabular}{lrr}
\hline & $\begin{array}{c}\text { Number } \\
(\mathrm{n}=22)\end{array}$ & $\begin{array}{c}\% \text { to } \\
\text { total }\end{array}$ \\
\hline Development of concessions for/partnerships with local people & 15 & 68.2 \\
Development of farmers' groups & 11 & 50.0 \\
Support for/training related to timber plants, NTFP, etc. & 9 & 40.9 \\
Facilitation of small-scale enterprises & 2 & 9.1 \\
\hline
\end{tabular}

Compared to the above-mentioned three aspects, fewer activities were described with regard to supervision of concession holders (Table 7). Twelve out of 17 FMUs (70.6\%) referred to periodic monitoring/checking of annual work plans. Five FMUs mentioned that they would conduct advising and monitoring for specific activities such as replanting. 
Table 7. Kinds of activities planned for supervising concession holders and numbers of FMUs that list them $(\mathrm{n}=17$ : those with concession holders)

\begin{tabular}{lrr}
\hline & $\begin{array}{c}\text { Number } \\
(\mathrm{n}=17)\end{array}$ & $\begin{array}{c}\% \text { to } \\
\text { total }\end{array}$ \\
\hline Periodic monitoring/ checking of annual work plans & 12 & 70.6 \\
Advice and monitoring of specific activities & 5 & 29.4 \\
Reporting to other authorities & 1 & 5.9 \\
\hline
\end{tabular}

In summary, the plans showed a large number of activities for utilization, not only of NTFPs or timber, but also ecosystems or carbon, and for conservation, such as patrolling or policing, fire management, relationships with local people, or enhancing infrastructure for forest management. Local empowerment was considered to be managed through official concessions for local people such as HTR or HKm. Interestingly, however, fewer ideas were presented with regard to concession supervision, and the activities presented were primarily those can be implemented without difficult negotiations with concession holders, such as monitoring of annual work plans. It is assumed that FMUs perceive difficulties in negotiating with existing company concession holders.

\subsection{Qualitative Assessments of Concreteness of Expressions}

Contrary to the fair number and various kinds of planned activities, however, the levels of concreteness of plan descriptions were low. Using the assessment metrics shown in Table 3, the numbers of FMUs assessed as Level 3 (mentioning concrete plans and methods for each activity, taking their local situations into consideration) were just four, four, three, and one, respectively (Table 8 ). Around $40 \%$ to $50 \%$ of FMUs fell into Level 1 (simply listing or describing what they would like to do or what FMUs are supposed to do, with few concrete plans or methods), and around $30 \%$ to $45 \%$ fell into Level 2 (explaining the activities and their significance, but expressions are general and lack local information or concreteness).

Table 8. Assessments of the levels of concreteness of plan descriptions using the matrix presented in Table 3

\begin{tabular}{lccc}
\hline \multicolumn{1}{c}{ Sub-chapter } & Level 1 & Level 2 & Level 3 \\
\hline Forest use in concession-free & 8 & 9 & 4 \\
areas (n=21) & $(38.1 \%)$ & $(42.9 \%)$ & $(19.0 \%)$ \\
Enforcement of forest protection & 11 & 7 & 4 \\
and nature conservation (n=22) & $(50.0 \%)$ & $(31.8 \%)$ & $(18.2 \%)$ \\
Empowerment of people (n=22) & 9 & 10 & 3 \\
Development and control of & $(40.9 \%)$ & $(45.5 \%)$ & $(13.6 \%)$ \\
concession-covered or & & & 1 \\
utilization-permit-covered areas & $(52.9 \%)$ & $(41.2 \%)$ & $(5.9 \%)$ \\
$(\mathrm{n}=17)$ & & & \\
\hline
\end{tabular}

These facts mean that $81.0 \%, 81.8 \%, 86.4 \%$, and $94.1 \%$ of the sample FMUs lacked concrete methods related to local contexts for utilization, conservation, local empowerment, and control of concession holders, respectively. This fact implies that in most of these sample FMUs, plans were formulated without proper information gathering.

Little evidence of statistical significance or tendency was found, except that the four FMUs evaluated as Level 3 in "Forest use in concession-free areas" were all in the West Sumatra province. This might be because local university academic staff were involved in and supported the development of FMUs; one such report is Mahdi et al. (2013). From the interviews in Lampung in 2013 and West Sumatra in 2016, there were several cases identified in which local universities supported the formulation of long-term plans for FMUs.

Regarding the expenses for each activity, only rough estimates were presented in the long-term forest management plans, with some notes that "the total amount and funding sources stipulated in this plan are used 
for planning activities, and do not constitute budget documents." Little evidence was found that the FMUs calculated the total amount needed for their activities in terms of financial feasibility. As mentioned earlier (in 3.1), for the national budget, FMUs request estimated annual budgets from the ministry with short-term forest management plans, and Directorates in charge at the ministry review them and determine budgetary allocations for FMUs.

\section{Discussion and Conclusion}

The author acknowledges that the present analysis is geographically confined to Sumatra, and hence simple generalization may not be appropriate. The author also acknowledges that the present study's insights might be only relevant to FMUs that were established at the initial phase (before August 2015, when the author obtained the data). Nevertheless, the findings of the present study can provide useful implications for ongoing FMU development broadly as follows.

It has been confirmed that although the FMUs refer to various activities in their long-term forest management plans, their planning tends to lack concreteness and selection-and-concentration strategies. A large portion of the sample FMUs simply listed or described what they would like to do or what FMUs are supposed to do. Considering insufficient human resources and unclear budgetary sources, it is difficult to assume that FMUs will be actually able to implement the planned activities. It is inferred that these long-term plans represent "wish lists" in given situations and resource availability, and whether all or most activities can be implemented was not necessarily taken into account.

The author proposes two factors that can explain the observed results. First, a lack of competencies and manpower of FMU personnel for policy formulation shall be taken into account. Regarding qualitative aspects of human resources, it is considered that current permanent personnel of FMUs are mostly those who were moved from provincial or district forestry services. It is probable that not all of them have sufficient skills and knowledge for formulating a long-term plan, taking diversity and uncertainty of the region into consideration. With regard to quantity of human resources, although the Indonesian government has recently implemented an internship program (Bakti Rimbawan) to dispatch university or college graduates to FMUs (MoEF, 2016), insufficiency of human resources is evident. Even if a few competent personnel were there, it would not be feasible to formulate a concrete plan and implement it. It would even be difficult for most FMUs to collect actual information inside the territory through forest resource surveys and substantive consultation with local people living there.

Second, financial vulnerability and unpredictability should be highlighted. As already explained, FMUs are highly dependent on budget schemes from the central government. FMUs request budgets for operational and activity costs from the ministry every year, with uncertainty about how much will be approved. Such a structure may lead to two consequences. One is that plan formulators may not able to deliberate plans in the long run. The other is that such a structure may give plan formulators an incentive to just list as many activities as possible to maximize the opportunities for approval by the ministry, although proposals for each activity are not necessarily concrete. Thus, vulnerable and unpredictable financial resources for FMUs can also explain the lack of concreteness in planning.

To promote substantive planning for FMUs, first, qualitative enhancement and quantitative increase of human resources are desirable. Second, policy options to reduce unpredictability and uncertainty in financial and institutional dimensions are also needed. Both issues might have been recognized by policy makers, and are at least partly being addressed (e.g., MoEF, 2014); the present study is supporting material, from the viewpoint of planning and its implementation, to confirm the necessity of the above-mentioned improvements.

\section{Acknowledgements}

The present study was funded by a Grant-in-Aid for Scientific Research (KAKEN No.16K16240). The author acknowledges the Ministry of Environment and Forestry in Indonesia for providing data.

\section{References}

Bae, J. S., Kim, Y. S., Fisher, L., Moeliono, M., \& DeShazo, J. (2014). Promises and perils of decentralized forest governance: the case of Indonesia's Forest Management Units in Reducing Emission from Deforestation and Forest Degradation (REDD+). Society \& Natural Resources, 27, 1346-1354. https://doi.org/10.1080/08941920.2014.945061

Bluffstone, R., \& Robinson, E. J. Z. (2014). Forest tenure reform in Asia and Africa: local control for improved livelihoods, forest management, and carbon sequestration. London: RFF Press. 
Damayanti, E. K., \& Prasetyo, L. B. (2015). Forest transition in Sumatra: driver, pressure, state, impact, and response. Poster Presentation at the National Seminar on Biodiversity Conservation at Southern Sumatra Sub-region, Palembang.

Fisher, L. A., Kim, Y. S., Latifah, S., \& Makarom, M. (2017). Managing forest conflicts: perspectives of Indonesia's Forest Management Unit directors. Forests and Society, 1, 8-26. http://dx.doi.org/10.24259/fs.v1i1.772

Gesellschaft für Internationale Zusammenarbeit [GIZ]. (2011). Capacity development for REDD readiness in pacific islands: the GIZ contribution. [Power Point slide] Retrieved December 22, 2016, from http://www.iges.or.jp/en/archive/fc/pdf/activity_20111110/7-GIZ.pdf

Hurst, P. (1990). Rainforest politics: ecological destruction in Southeast Asia. London, New Jersey: Zed Books Limited

Kim, Y. S., Bae, J. S., Fisher, L. A., Latifah, S., Afifi, M., Lee, S. M., \& Kim, I. A. (2016). Indonesia's Forest Management Units: effective intermediaries in REDD + implementation? Forest Policy and Economics, 62, 69-77. https://doi.org/10.1016/j.forpol.2015.09.004

Limberg, G., Iwan, R., Moeliono, M., Sudana, M., \& Wollenberg, E. (2007). Community-based forestry and management planning. In P. Gunarso, T. Sety-Awati, T. C. H. Sunderland, \& C. Shackleton (Eds.), Managing forest resources in a decentralized environment: lessons learnt from the Malinau Research Forest, East Kalimantan, Indonesia (pp. 107-127). Bogor: Center for International Forestry Research.

Mahdi, A. A., Senatung, M., \& Helmi. (2013, June). Developing organizational structure of Kesatuan Pengelolaan Hutan (KPH) Limapuluh Kota District, West Sumatra, Indonesia, for sustainable forest management. Paper presented at the $14^{\text {th }}$ Global Conference of the International Association for the Study of the Commons, Kitafuji, Japan. Abstract Retrieved from https://dlc.dlib.indiana.edu/dlc/bitstream/handle/10535/8928/MAHDI_1148.pdf?sequence=1

Margono, B. A., Potapov, P. V., Turubanova, S., Stolle, F., \& Hansen, M. C. (2014). Primary forest cover loss in Indonesia over 2000-2012. Nature Climate Change, 4, 730-735.

Mendes, A. (2006). Implementation analysis of forest programmes: some theoretical notes and an example. Forest Policy and Economics, 8, 512-528. https://doi.org/10.1016/j.forpol.2005.07.003

Ministry of Environment and Forests [MoEF]. (2014). Strategies for developing Forest Management Units and structural transformations of forestry in Indonesia. Jakarta: Ministry of Environment and Forestry. (in Indonesian)

Ministry of Environment and Forests [MoEF]. (2015). Supplements, Work Plan 2015 (Revision). Jakarta: Ministry of Environment and Forestry. (in Indonesian)

Ministry of Environment and Forests [MoEF]. (2016). Forester Service. Retrieved December 22, 2016 from http://bp2sdm.menlhk.go.id/loker/baktirimbawan/ Accessed 22 December 2016. (in Indonesian)

Ministry of Environment and Forests [MoEF]. (2017). System for spatial information and documentation for Forest Management Units. Retrieved December 15, 2017, from http://kph.menlhk.go.id

Ministry of Forestry [MoF]. (2011). Forest Management Unit development: concept, legislation and implementation. Jakarta: Ministry of Forestry.

Ngakan, P. O., Achmad, A., William, D., Lahae, K., \& Tako, A. (2005). The dynamics of decentralization in the forestry sector in South Sulawesi: the history, realities and challenges of decentralized governance. Bogor: Center for International Forestry Research.

Ota, M. (2015). Can Forest Management Units improve the management of state forests in Indonesia's outer islands? Institutional analysis and case studies from Lampung province of Sumatra. International Forestry Review, 17, 76-85. https://doi.org/10.1505/146554815814725121

Sahide, M. A. K., Maryudi, A., Supratman, S., \& Giessen, L. (2016a). Is Indonesia utilising its international partners? the driving forces behind Forest Management Units. Forest Policy and Economics, 69, 11-20. https://doi.org/10.1016/j.forpol.2016.04.002

Sahide, M. A. K., Supratman, S., Maryudi, A., Kim, Y. S., \& Giessen, L. (2016b). Decentralisation policy as recentralisation strategy: Forest Management Units and community forestry in Indonesia. International Forestry Review, 18, 78-95. https://doi.org/10.1505/146554816818206168 
Setyarso, A. (2016). Development of permanent Forest Management Units and new governance for forest concessions in Indonesia. [Power Point slides]. Retrieved December 15, 2017, from http://www.fao.org/forestry/45317-05cfb02ddfedd2da160041c85eb4bde7d.pdf

Springate-Baginski, O., \& Blaikie, P. (2007). Forests people and power: the political ecology of reform in South Asia. London: Earthscan Publishers.

Stevens, D. D., \& Levi, A. (2013). Introduction to rubrics: an assessment tool to save grading time, convey effective feedback, and promote student learning (2nd ed). Sterling: Stylus Publishing.

Sunderlin, W., Hatcher, J., \& Liddle, M. (2008). From exclusion to ownership? Challenges and opportunities in advancing forest tenure reform. Washington DC: Rights and Resource Initiative.

The Center for People and Forests [RECOFTC]. (2016). Capacity development. Retrieved December 22, 2016, from

http://www.recoftc.org/project/asean-swiss-partnership-social-forestry-and-climate-change/basic-page/capa city-development

\section{Note}

Note 1. The Law on Regional Government (UU 23 2014) was implemented in Indonesia beginning in October 2014. According to this law, forest management is stipulated as an issue over which provincial governments are in charge. FMUs established at the district level are considered to be contradictory to this law, and hence the change of status of district FMUs to provincial FMUs is currently being processed.

\section{Copyrights}

Copyright for this article is retained by the author(s), with first publication rights granted to the journal.

This is an open-access article distributed under the terms and conditions of the Creative Commons Attribution license (http://creativecommons.org/licenses/by/4.0/). 